\title{
Peranan Pendidikan Agama Dalam Keluarga Terhadap Pembentukan Kepribadian Anak-Anak
}

\author{
Nurmadiah \\ Dosen Jurusan Manajemen Pendidikan Islam, Fakultas Ilmu Agama \\ Islam, Universitas Islam Indragiri (UNISI) Tembilahan
}

\begin{abstract}
Abstrak
Dalam kehidupan manusia, pendidikan memiliki peranan penting dalam membentuk generasi mendatang. Dengan pendidikan diharapkan dapat menghasilkan manusia berkualitas, bertanggung jawab dan mampu meng-antisipasi masa depan. Pendidikan dalam maknanya yang luas senantiasa menstimulir, menyertai perubahan-perubahan dan perkembangan umat manusia. Selain itu, upaya pendidikan senantiasa menghantar, membimbing perubahan dan perkembangan hidup serta kehidupan umat manusia. Keluarga merupakan sebuah pondasi dan institusi yang paling dicintai dalam Islam. Untuk menciptakan keluarga yang baik, pendidikan agama memiliki peran penting dalam pembentukannya. Pendidikan agama di lingkungan keluarga sangat besar peranannya dalam pembentukan kepribadian bagi anak-anak, karena di lingkungan keluargalah anak-anak pertama kali menerima pendidikan yang dapat mempengaruhi perkembangan anak selanjutnya. Agar anak-anak memiliki kepribadian yang baik dan terhindar dari pelanggaran-pelanggaran moral, maka perlu adanya pembinaan agama sejak dini kepada anak-anak dalam keluarga. Proses pembinaan nilai-nilai agama dalam membentuk kepribadian anak-anak dapat dimulai sejak anak lahir sampai ia dewasa. Ketika lahir diperkenalkan dengan kata-kata thoyyibah, kemudian setelah mereka tumbuh dan berkembang menjadi anak-anak, maka yang pertama harus ditanamkan ialah nilai-nilai agama yang berkaitan dengan keimanan, sehingga anak meyakini adanya Allah dan dapat mengenal Allah dengan seyakin-yakinnya (ma'rifatullah). Bersamaan dengan itu, anak-anak juga dibimbing mengenai nilai-nilai moral, seperti cara bertutur kata yang baik, berpakaian yang baik, bergaul dengan baik, dan lain-lainnya. Kepada anak-anak juga ditanamkan sifat-sifat yang baik, seperti nilai-nilai kejujuran, keadilan, hidup serderhana, sabar dan lain-lainnya. Selain itu, agar anak-anak memiliki nilai-nilai moral yang baik di dalam keluarga, khususnya antara ibu dan bapak harus menjaga harmonisasi hubungan antara keduanya dan harus menjadi suri tauladan bagi anak-anaknya.
\end{abstract}

Key Words: Pendidikan Agama, Pembentukan kepribadian anak 


\section{A. Pendahuluan}

Disamping peranan pendidikan yang menjadi dasar dalam pembentukan kepribadian anak. Orang tua juga memegang peran yang penting dalam pembentukan kepribadian anak-anak. Baik buruknya kepribadian anak-anak di masa yang akan datang banyak di tentukan oleh pendidikan agama dan bimbingan orang tuanya. Karena didalam keluarga itulah anak-anak pertama kali memperoleh pendidikan sebelum pendidikan-pendidikan yang lain. Sejak anak lahir dari rahim ibunya sampai anak-anaknya dewasa orang tua selalu mendidik, menjaga, merawat mereka dengan penuh kasih sayang dengan harapan kelak mereka dapat tumbuh besar dan berkembang menjadi manusia dewasa yang baik, yang sesuai dengan ajaran agama Islam. Pendidikan yang diberikan di lingkungan keluarga berbeda dengan pendidikan yang diberikan di sekolah, karena pendidikan di lingkungan keluarga bersifat informal, yang tidak terikat oleh waktu dan program pendidikan secara khusus, sebagaimana lembaga pendidikan sekolah.

Pendidikan dalam keluarga berjalan sepanjang masa, melalui proses interaksi dan sosialisasi didalam keluarga itu sendiri. Esensi pendidikannya tersirat dalam integritas keluarga, baik didalam komunikasi antara sesama keluarga, dalam tingkahlaku keseharian orang tua, dan keluarga lainnya,juga dalam hal-hal lainnya yang berjalan dalam keluarga semuanya merupakan proses pendidikan bagi anak-anak. Oleh karena itu orang tua harus selalu memberikan contoh tauladan yang baik bagi anak-anak mereka, karena apapun kebiasaan orang tua di rumah akan selalu dilihat, dicerna dan bahkan sampai akan diritu oleh anak-anak.

Sebagai lingkungan pendidikan yang pertama, keluarga memegang peran yang sangat besar dalam membentuk pola kepribadian anak. Oleh karena itu orang tua sebagai penanggung jawab atas kehidupan keluarga harus memberikan pendidikan dan pengajaran kepada anak-anaknya dengan menanamkan pendidikan agama dan akhlak yang baik dalam kehidupan sehari-hari.

Sejalan dengan semakin pesatnya era globalisasi yang dicirikan dengan derasnya arus informasi dan teknologi, ternyata dari satu sisi memunculkan persoalan-persoalan baru yang kerap kali kita temukan pada diri individu dalam suatu masyarakat. Munculnya kenal- 
akan remaja, tawuran antar pelajar, narkoba, penyimpangan seksual, kekerasan antara anak-anak, terkadang sampai anak tega menyakiti orang tuanya sendiri, serta berbagai bentuk penyimpangan penyakit kejiwaan, seperti stres, depresi, dan kecemasan, bahkan sampai bunuh diri. Adalah bukti yang tidak bisa dinafikan ditengah-tengah masyarakat kita sekarang ini, yang merupakan dampak negatif dari kemajuan peradaban kita. Hal ini secara tidak langsung berpengaruh tidak baik pula pada kemapanan dan tatanan masyarakat damai seperti yang kita harapkan semua.

Masalah kepribadian merupakan suatu masalah yang menjadi perhatian orang dimana saja, baik dalam masyarakat yang telah maju maupun bagi masyarakat yang masih terbelakang. Karena kerusakan moral seseorang merupakan ciri kepribadian orang tersebut dan dapat mengganggu ketentraman orang lain. Jika didalam suatu masyarakat banyak yang rusak moralnya, maka akan tidak amanlah keadaan masyarakat tersebut.

Jika kita tinjau keadaan masyarakat di Indonesia terutama di kota-kota besar sekarang ini, akan kita dapati bahwa sebagian anggota masyarakat memiliki kepribadian yang buruk. Dimana kita lihat, kepentingan umum tidak lagi menjadi nomor satu, akan tetapi kepentingan dan keuntungan pribadilah yang menonjol pada banyak orang.

Kejujuran, keberanian, keadilan, dan kebenaran telah tertutup oleh penyelewengan-penyelewengan,baik yang terlihat ringan maupun berat. Banyak terjadi adu domba, hasud dan fitnah, menjilat, menipu, berdusta, mengambil hak orang lain sesuka hati, disamping juga perbuatan-perbuatan maksiat lainnya.

Orang-orang yang dihinggapi kepribadian buruk, tidak saja orang yang telah dewasa, akan tetapi sudah menjalar sampai kepada generasi muda yang kita harapkan untuk menjadi generasi penerus untuk melanjutkan perjuangan membela nama baik bangsa dan negara kita. Belakangan ini kita banyak mendengar keluhan-keluhan orang tua, para pendidik, dan orang-orang yang berkecimpung dalam bidang sosial dan agama, anak-anak yang terutama berumur belasan tahun dan mulai remaja, mulai sulit dikendalikan, nakal, keras kepala, suka melawan, berbuat keonaran, maksiat, narkoba, bahkan akhir-akhir ini anak-anak sekolah berani melemparkan air 


\section{$92 \frac{\text { Jurnal AL-AFKAR }}{\text { Vol. II, No. II, Oktober } 2013}$}

keras ke penumpang bus yang terjadi di Jakarta, dan hal-hal yang mengganggu ketentraman umum.

Buruknya kepribadian yang disebutkan di atas mencerminkan kelakuan anak-anak yang menggelisahkan orang tuanya sendiri bahkan sampai meresahkan masyarakat yang ada di sekitar keberadaan anak-anak tersebut. Baik yang berkaitan masyarakat sekolah, maupun masyarakat umum, bahkan sampai ada yang menggelisahkan dirinya sendiri. Tidak sedikit orang tua yang mengeluhkan kebingungan menghadapi anak-anak yang tidak bisa lagi dikendalikan baik orang tuanya sendiri maupun oleh guru-gurunya. Contoh-contoh dalam hal ini sangat banyak, kita saksikan dan kita perhatikan sendiri dan kiranya tidak perlu kita paparkan disini.

Berdasarkan uraian di atas, perlu kiranya kita memikirkan tentang model pendidikan anak-anak di lingkungan keluarga, sehingga anak-anak remaja kita memiliki kepribadian yang baik yang akan berdampak pula ke depan terhadap bangsa ini.

Pembahasan dalam materi ini dimaksudkan untuk mengetahui: (1) peranan keluarga bagi anak-anak, (2) faktor-faktor yang menyebabkan memiliki kepribadian yang buruk, (3) peranan pendidikan agama dalam lingkungan keluarga terhadap pembentukan kepribadian anak.

\section{B. PEMBAHASAN}

\section{a. Peranan Keluarga Bagi Anak}

Keluarga secara etimologis berasal dari rangkaian kata "kawula" dan "warga". kawula artinya abdi yakni hamba, sedangkan warga artinya anggota. Sebagai abdi didalam keluarga, seorang wajib menyerahkan segala kepentingannya kepada keluarganya dan warga atau anggota. Ia berhak untuk ikut mengurus segala kepentingan di dalam keluarganya. ${ }^{1}$

Sedangkan menurut M. I Sulaiman, ${ }^{2}$ ciri hakiki suatu keluarga adalah bahwa keluarga itu merupakan: "satu persekutuan hidup yang dijalin kasih sayang antara pasangan dua jenis manusia yang dikukuhkan dengan pernikahan, yang bermaksud untuk saling me-

1 Ihat Hatimah dkk, Pembelajaran Berwawasan Masyarakat, (Jakarta: Universitas terbuka; 2007), hal. 34

2 M.I. Seolaeman, Pendidikan dalam Keluarga. Diktat Kuliah(1978), hal. 12 
nyempurnakan diri”.

Dalam ensyclopedi umum yang dimaksud dengan keluarga yaitu kelompok orang yang ada hubungan darah atau perkawinan yang terdiri dari ibu, ayah, anak-anaknya ( yang belum memisahkan diri sebagai keluarga).

Dalam bahasa Inggris kata keluarga di artikan dengan family. Everet wilson mengartikan family (keluarga) adalah "the face to face group" (kelompok tatap muka). Dia mengartikan lebih ke arah fungsi keluarga.

Keluarga merupakan unit terkecil dalam masyarakat, yang terdiri dari ayah, ibu, anak-anak, dan kerabat lainnya. Lingkungan keluarga merupakan tempat dimana anak-anak di besarkan dan merupakan lingkungan pertama kali dijalani oleh seorang anak dalam mengarungi hidupnya, sehingga apa yang dilihat dan dirasakan oleh anak-anak dalam keluarga akan dapat mempengaruhi pertumbuhan dan perkembangan jiwa seorang anak. ${ }^{3}$

Keluarga merupakan unit pertama dan institusi pertama dalam masyarakat dimana hubungan-hubungan yang terdapat didalamnya, sebahagian bersifat hubungan langsung dan disitulah berkembang individu dan disitu pulalah terbentuknya tahap-tahap awal proses sosialisasi bagi anak-anak. Dari interaksi dalam keluarga inilah anak-anak memperoleh pengetahuan, keterampilan, nilai-nilai, dan sikapnya dalam hidup dan dengan itu pulalah mereka memperoleh ketenangan dan ketentraman hidup.

Pembentukan keluarga dalam Islam bermula dengan terciptanya hubungan suci yang menjalin seorang laki-laki dan seorang perempuan, melalui perkawinan yang halal, memenuhi rukun-rukun dan syarat-syarat sahnya perkawinan tersebut. Oleh karena itu, kedua suami istri itu merupakan unsur utama dalamkeluarga. Jadi, keluarga dalam pengertiannya yang sempit merupakan suatu unit sosial yang terdiri dari seorang suami dan seorang istri, atau dengan kata lain, keluarga adalah perkumpulan yang halal antara seorang laki-laki dan seorang perempuan yang bersifat terus menerus dimana yang satu merasa tentram dengan yang lain sesuai dengan yang ditentukan oleh agama dan masyarakat. Dan ketika kedua suami istri itu

3 Rohmat Mulyana,Cakrawala Pendidikan Umum, Bandung: Ikatan Mahasiswa dan Alumni Pendidikan Umum (IMA-PU) PPS IKIP Bandung; 1999), hal. 42 
dikaruniai anak, maka anak-anak itu merupakan unsur utama ketiga pada keluarga tersebut disamping dua unsur utama sebelumnya.

Keluarga merupakan lingkungan pertama bagi setiap individu dimana dia berinteraksi. Dari interaksi dengan lingkungan pertama inilah individu memperoleh ciri-ciri dan unsur-unsur dasar dalam kepribadiannya. Juga dari situlah dia memperoleh akhlak, nilai-nilai, kebiasaan dan emosinya dan dengan itu dia merubah banyak kemungkinan-kemungkinan, kesanggupan-kesanggupan dan kesediaannyamenjadi kenyataan dalam hidupdan tingkahlaku yang tampak. Jadi keluarga itu bagi seorang individu merupakan simbol atas nilai-nilai yang mulia, seperti keimanan yang teguh kepada Allah, pengorbanan, kesediaan berkorban untuk kepentingan kelompok, cinta kepada kebaikan, kesetiaan, dan nilai-nilai lainnya yang mulia, yang dengannya keluarga dapat menolong individu untuk menanamkannya pada dirinya. ${ }^{4}$

Individu itu perlu pada keluarga bukan hanya pada tingkat awal kehidupnya dan pada masa kanak-kanak, tetapi dia memerlukannya sepanjang hidupnya, karena didalam keluargalah baik anakanak, remaja, orang dewasa, orang tua, dan manula mendapatkan rasa kasih sayang, rasa tentram, dan ketenangan.

Keberadaan keluarga bukan hanya penting bagi seorang individu tetapi juga bagi masyarakat, sehingga masyarakat menganggap keluarga sebagai institusi sosial penting dan merupakan unit sosial yang utama melalui individu-individu yang telah dipersiapkan didalamnya, baik berupa kebudayaan, nilai-nilai, kebiasaan, maupun tradisi yang ada didalamnya. Dari segi inilah, maka keluarga dapat menjadi ukuran dalam sebuah masyarakat, dalam arti apabila masing-masing keluarga berada dalam keluarga yang sehat, maka akan sehatlah suatu masyarakat, dan begitu pula sebaliknya, jika keluarga itu tidak sehat, maka dampaknya terhadap keluarga pun akan menjadi tidak sehat.

Keluarga sebagai tempat dimana anak-anak dibesarkan memiliki peranan yang sangat penting dalam pendidikan anak, karena pertama-tama yang akan dilihat dan dirasakan oleh anak sebelum orang lain adalah keluarga. Pendidikan keluarga tidak akan tergeser

4 Djahiri. A. K, Menelusuri Dunia Efektif, pendidikan Nilai dan Moral, Bandung: Lab. PMP IKIP; 1966), hal. 19 
oleh banyaknya institusi-institusi dan lembaga-lembaga pendidikan yang ada, seperti Taman Kanak-Kanak, Sekolah-sekolah, akademi-akademi dan lain-lainnya. Begitu juga dengan bertambahnya lembagalembaga kebudayaan, kesehatan, politik, agama tidak akan menggeser fungsi kedudukan keluarga.

Walaupun begitu tingginya tingkat perkembangan dan perubahan yang berlaku disebahagian besar masyarakat modern, termasuk masyarakat muslim sendiri, tetapi keluarga tetap memelihara fungsi pendidikannya dan menganggap bahwa hal itu merupakan sebagian tugasnya, khususnya dalam rangka menyiapkan sikap cinta mencintai dan keserasiaan diantara anggota-anggotanya. Begitu juga ia harus memberi pemeliharaan kesehatan, psikologikal, spiritual, akhlak, jasmani, intelektual, emosional, dan sosial disamping menolong mereka menumbuhkan pengetahuan, ketrampilan, sikap dan kebiasaan, yang diingini yang berguna bagi segala lapangan hidup mereka serta sanggup mengambil pelajaran dari lembaga-lembaga lain..$^{5}$

Peranan pendidikan yang sepatutnya di pegang oleh keluarga bagi anggota-anggotanya secara umum adalah peranan yang paling pokok dibanding peranan-peranan lainnya.Lembaga-lembaga lain dalam masyarakat, misalnya lembaga politik, ekonomi, kebudayaan dan lain-lain tidak dapat memegang peranan itu. Walaupun lembagalembaga lain dapat menolong keluarga dalam tindakan pendidikan, akan tetapi ia tidak sanggup untuk menggantikannya, kecuali dalam keadaan-keadaan luarbiasa. Seperti ibu bapak meninggal atau ibu bapak rusak akhlak dan menyeleweng dari kebenaran, atau mereka acuh tak acuh dan tidak tahu cara mendidikan anak dengan benar. Orang tua semacam ini tidak akan sanggup mendidik anak-anaknya menjadi orang terhormat dan baik. Karenanya akan menjadi mashlahat apabila anak-anak itu dididik di luar keluarga mereka. Misalnya dalam institusi-institusi yang baik, teratur dan bertanggung jawab atas baik dan buruknya kepribadian. ${ }^{6}$

5 Ibid., Hal. 31

6 Rohmat Mulyana, Mengartikulasikan Pendidikan Nilai, (Bandung: Alfabeta; 2004), hal. 24 
Menurut Syamsu Yusuf, ${ }^{7}$ keluarga dipandang sebagai penentu utamapembentukan kepribadian anak. Alasannya adalah: (1) keluarga merupakan kelompok sosial pertama yang menjadi pusat indentifikasi anak, (2) anak banyak menghabiskan waktunya di lingkungan keluarga, dan (3) para anggota keluarga merupakan "significant people" bagi pembentukan kepribadian anak.

Di samping itu keluarga juga dipandang sebagai lembaga yang dapat memenuhi kebutuhan insani, terutama bagi pengembangan kepribadiannyadan pengembangan ras manusia. Melalui perlakukan dan perawatan yang baik dari orang tua, anak dapat memenuhi kebutuhannya, baik kebutuhan fisik-biologis, maupun kebutuhan sosio psikologisnya. Apabila anak dapat memenuhi kebutuhan-kebutuhan dasarnya, maka dia cenderung berkembang menjadi seorang pribadi yang sehat.

Perlakukan orang tua yang penuh kasih sayang dan pendidikan nilai-nilai kehidupan, baik nilai agama maupun nilai budaya sosial yang diberikan kepada anakmerupakan faktor yang kondusif untuk mempersiapkan anak menjadi pribadi dan warga masyarakat yang sehat dan produktif.

Suasana keluarga sangat penting bagi perkembangan kepribadian anak, seorang anak yang dibesarkan dalam lingkungan keluarga yang harmonis dan agamis, yaitu suasana yang memberikan curahan kasih sayang, perhatian, dan bimbingan dalam bidang agama, maka perkembangan kepribadian anak tersebut cenderung positif dan sehat. Sedangkan anak yang dikembangkan dalam lingkungan keluarga yang berantakan, tidak harmonis, keras terhadap anak dan tidak memperhatikan nilai-nilai agama, maka perkembangan kepribadiannya cenderung mengalami distorsi atau mengalami kelainan dalam penyesuaian dirinya.

Apabila fungsi keluarga dalam kajian psikologikal modern menekankan pendidikannya pada pembinaan jiwa mereka dengan rasa cinta, kasih sayang,dan ketentraman, justru para ahli jiwa muslim jauh sebelum itu telah menekankan perkara ini dalam berbagai tulisannya. Ulama-ulama muslim dahulu kala menekankan pentingnya peranan pendidikan keluarga itu pada tahun-tahun pertama usia anak-anak yang berdasarkan pada pengalaman-pengalaman mereka

7 Syamsu yusuf, Meretas Pendidikan Nilai, (Bandung: Arfino Raya; 2007), hal. 15 
sendiri. Disamping itu, nash-nash al-Qur'an dan as-Sunnah banyak yang menekankan pentingnya pendidikan dalam keluarga. Di antaranya Allah swt. berfirman, "Peliharalah dirimu dan keluargamu dari api neraka." (QS.66:6). Juga Rasulullah saw. bersabda, "Setiap bayi yang dilahirkan dalam keadaan fitrah, maka ibu bapaknya lah yang menjadikan dia Yahudi, Nasrani, atau Majusi (HR. At-Tabrani dan Baihaqi). Dalam sabdanya yang lain, Rasulullah menjelaskan, "Awasi lah anak-anakmu dan perbaikilah adabnya." (HR. Ibnu Majah)

Dari bukti-bukti yang dikemukakan di atas, menunjukkan bahwa mendidik anak dalam keluarga kewajiban paling utama. Kewajiban ini tidak dapat ditinggalkan kecuali karena udzur, dan tidak akan membebaskan dia dari tanggung jawab ini dengan adanya institusi-institusi pendidikan yang didirikan khusus untuk anak-anak dan generasi muda. Sebab institusi itu tidak akan sanggup mengganti keluarga dalam menanamkan rasa cinta dan kasih sayang kepada anak-anak.

Keluarga merupakan pendidik utama dan pertama, pertama karena lingkungan awal sebelum anak itu mengenal luar dan utama karena keluarga menjadi lingkungan sosial dan emosional dimana hal itu sangat memberikan kualitas pengalaman sehingga menjadi faktor determinan untuk pembentukan kepribadian seorang anak. ${ }^{8}$

Menurut M.I. Sulaiman, ${ }^{9}$ fungsi keluarga itu ada delapan jenis yaitu: (1) fungsi edukasi, (2) fungsi sosialisasi, (3) fungsi proteksi, (4) fungsi afeksi, (5) fungsi religius, (6) fungsi ekonomi, (7) fungsi rekreasi, (8) fungsi biologis.

Berdasarkan pada beberapa fungsi di atas, terlihat bahwa salah satu fungsi keluarga adalah fungsi pendidikan. Hal ini berarti bahwa orang tua sebagai pendidik utama dan pertama mempunyai kewajiban dalam memberikan pendidikan kepada anak-anaknya termasuk pendidikan nilai moral pada anaknya.

\section{b. Faktor-Faktor yang Mempengaruhi Kepribadian}

Kepribadian yang dimiliki seseorang tidak lepas dari pengaruh yang datang dari luar dirinya. Paling tidak ada tiga faktor utama

8 Abdullah Nasih Ulwan, Pendidikan Anak dalam Islam, (Jakarta: pustaka Imani; 2007), hal. 57

9 M.I. Seolaeman. Op. Cit., hal. 84 


\section{$98 \frac{\text { Jurnal AL-AFKAR }}{\text { Vol. II, No. II, Oktober } 2013}$}

yang bekerja didalam menentukan perkembangan kepribadian seseorang. Pertama, pengaruh keturunan individu, kedua, pengalaman awal didalam keluarga, ketiga, peristiwa-peristiwa penting di kemudian hari di luar lingkungan rumah. Dengan demikian, pola kepribadian bukanlah hasil belajar secara eksklusif. Sebaliknya, itu berasal dari interaksi dari keduanya. ${ }^{10}$

Kepribadian yang dimiliki seseorang tidak bisa lepas dari faktor keturunan, terutama yang berkaitan dengan pematangan karakteristik fisik dan mental. Meskipun faktor lingkungan sosial dan lainnya besar pengaruhnya terhadap kepribadian, namun tidak lepas dari potensi yang ada dalam individu. Bahan baku utama kepribadian, sepertti fisik, kecerdasan, dan tempramen adalah hasil dari keturunan. Anak memiliki warisan-warisan sifat bawaan yang berasal dari kedua orang tuanya, merupakan potensi tertentu yang terbentuk dan sukar dirubah. Menurut H.C. Whiterington dalam Uyoh Sa'dullah, ${ }^{11}$ heriditas adalah proses penurunan sifat-sifat atau ciri-ciri tertentu dari suatu generasi ke generasi lain dengan perantaraan sel benih. Pada dasarnya yang diturunkan itu adalah struktur tubuh. Jadi, apa yang diturunkan orang tua kepada anak-anaknya berdasarkan kepada perpaduan gen-gen yang pada umumnya hanya mencakup sifat atau ciri-ciri struktur individu. Yang diturunkan itu sangat kecil menyangkut ciri atau sifat orang tua yang diperoleh dari linggkungan atau hasi belajar dari lingkungannya. Beberapa ciri atau sifat orang tua yang kemungkinan dapat diturunkan, misalnya; warna kulit, kecerdasan, bentuk fisik seperti, bentuk mata, hidung dan lain sebagainya yang berkaitan dengan struktur fisik individu.

Selain dipengaruhi oleh faktor keturunan, kepribadian juga terbentuk dari interaksi figur yang signifikandari semua anggota keluarga (pertama ibu, kemudian ayah dan saudara, dan kemudian figurkeluarga yang lainnya) dengan anak. Anak itu membawa kepada interaksi ini, seperti konstitusi biologis tertentu, kebutuhan tertentu, dan kapasitas intelektual tertentu yang menentukan reaksinya dengan cara dimana dia menindaklanjuti figur yang signifikan tersebut.

10 Linda N.Eyre Richard, Teaching Your Children Values, (New York: Simon Sand Chuster; 1995), hal. 24

11 Uyoh Sa'dullah (2007:65) 
Dalam interaksi antara faktor dan lingkungan, individu memilih dari lingkungannya apa yang sesuai dengan kebutuhan dan keinginan dan menolak apa yang tidak disukainya. Oleh karena itu, pola kepribadian berkembang dimulai dari interaksi dengan lingkungan sendiri.

Selanjutnya, pengakuan keterbatasan yang dikenakan oleh keturunan menggaris bawahi fakta bahwa orang tidak benar-benar bebas untuk memilih dan mengembangkan jenis pola kepribadian yang mereka inginkan denganmenggunakan kecerdasan. Sebagai ilustrasi: seseorang dengan kecerdasan tingkat rendah tidak dapat mengembangkan pola kepribadian seorang pemimpin meskipun ia ingin melakukannya dan walaupun keinginannya memberinya motivasi yang kuat untuk coba mengembangkan ciri kepribadian yang penting untuk kepemimpinannya.

Pendidikan dalam berbagai bentuk, khususnya atau belajar di bawah bimbingan dan arahan yang lain, memainkan peran utama dalam pengembangan pola kepribadian. Sikap terhadap diri, model karakteristik menanggapi orang dan situasi, sikap terhadap asumsi peran sosial yang disetujui, dan metode penyesuaian pribadi dan sosial,termasuk penggunaan mekanisme pertahanan, dipelajari melalui pengulangan dan diperkuat oleh kepuasan yang mereka bawa. Secara bertahap, konsep diri dibangun dan tanggapan belajar menjadi kebiasaan, yang menjadi ciri dalam pola kepribadian individu.

Ada dua alasan, mengapa pendidikan memainkan peran dalam pengembangan pola kepribadian, yaitu; pertama, ia memberi tahu kita bahwa pengendalian dapat dilaksanakan untuk memastikan bahwa individu akan mengembangkan jenis pola kepribadian yang akan dapat menyesuaikan pribadi dan sosial yang baik. Kedua, hal itu mengatakan kepada kita bahwa konsep diri yang tidak sehat dan pola sosial tidak dapat diterima penyesuaiannya dapat diubah dan dimodifikasi. Seperti dalam mempelajari semua, semakin cepat perubahan atau modifikasi dicoba, akan semakin mudah.

\section{c. Faktor-Faktor Penyebab Anak Berpribadi Buruk}

Apabila kita analisis faktor-faktor yang menyebabkan anakanak memiliki kepribadian buruk, sehingga mengakibatkan merosot- 
nya moral pada masyarakat banyak sekali. Menurut Zakiyah Drajat ${ }^{12}$ (1988:84), antara lain yang terpenting adalah :

1. Kurang tertanamnya jiwa agama pada tiap-tiap orang dalam masyarakat

Keyakinan beragama yang didasarkan ataspengertian yang sungguh-sungguh dan sehat tentang ajaran agama yang dianutnya, kemudian diringi dengan pelaksanaan ajaran-ajaran tersebut merupakan benteng moral yang paling kokoh. Apabila keyakinan beragama itu betul-betul telah menjadi bagian integral dari kepribadian seseorang, maka keyakinannya itulah yang akanmengawasi segala tindakan, perkataan bahkan perasaannya. Jika terjadi tarikan orang kepada sesuatu yang kelihatannya menyenangkan dan menggembirakan, maka keimanannya cepat bertindak meneliti apakah hal tersebut boleh atau terlarang dalam agama.

Jika setiap orang kuat keyakinannya kepada Tuhan, mau menjalankan agama dengan sungguh-sungguh, maka tidak perlu polisi, tidak perlu pengawasan yang ketat, karena setiap orang dapat menjaga dirinya sendiri, tidak mau melanggar hukumhukum dan ketentuan Tuhannya. Semakin jauh masyarakatdari agama, semakin sulit menjaga moral orang dalam masyarakat itu, dan semakin kacaulah suasana, karena semakin banyaknya pelanggaran-pelanggaran atas hak dan hukum.

2. Keadaan masyarakat yang kurang stabil, baik dari segi ekonomi, sosial, dan politik

Faktor kedua yang ikut mempengaruhi moral masyarakat ialah kurang stabilnya keadaan, baik ekonomi, sosial, maupun politik. Kegoncangan atau ketidakstabilan suasana yang melingkungi seseorang menyebabkan gelisah dan cemas, akibat tidak dapatnya mencapai rasa aman dan ketentraman dalam hidup. Demikian juga dengan keadaan sosial dan politik, jika tidak stabil, maka akan menyebabkan orang merasa takut, cemas, dan gelisah dan keadaan seperti ini akan mendorong pula pada kelakuan-kelakuan yang mencari rasa aman yang kadang-kadang menimbulkan kecurigaan, tuduhan-tuduhan yang tidak berala-

12 Zakiyah Drajat, Membina Nilai-nilai Moral di Indonesia, (Jakarta: Bulan Bintang; 1988), hal. 84 
san, kebencian kepada orang lain, adu domba, fitnah, dan lain sebagainya. Hal ini semua mudah terjadi pada orang yang kurang keyakinannya kepada agama, dan mudah menjadi gelisah.

3. Pendidikan moral tidak terlaksana menurut semestinya, baik di rumah tangga, sekolah, dan masyarakat

Faktor ketiga yang juga cukup penting adalah tidak terlaksannya pendidikan moral dengan baik dalam rumahtangga, sekolah, dan masyarakat.Pembinaan moral seharusnya dilaksanakan sejak anak kecil sesuai dengan kemampuan dan umurnya. Karena setiap anak lahir belum mengerti mana yang benar dan mana yang salah, dan belum tahu batas-batas dan ketentuan moral yang berlaku dalam lingkungannya. Tanpa di biasakan menanamkkan sikap-sikap yang dinaggap baik untuk pertumbuhan moral, anak-anak akan dibesarkan tanpa mengenal moral itu. Juga perlu diingat bahwapemahaman tentang moral belum dapat menjamin tindakan moral. Moral bukanlah suatu pelajaran atau ilmu pengetahuan yang dicapai dengan mempelajari tanpa membiasakan hidup bermoral dari kecil, karena moral itu tumbuh dari tindakan kepada pengertian. Disinilah peranan orang tua, guru, dan lingkungan yang sangat penting. Jika anak dilahirkan dan dibesarkan oleh orang tua yang tidak bermoral atau tidak tahu cara mendidik yang baik, ditambah lagi dengan keadaan masyarakat yang goncang dan kurang mengindahkan moral, maka sudah barang tentu hasil yang akan terjadi tidak menggembirakan dari segi moral.

4. Suasana rumah tangga yang kurang baik

Faktor yang terlihat pula dalam masyarakat sekarang adalah kerukunan hidup dalam rumah tangga kurang terjamin. Tidak tampak adanya saling pengertian,saling menerima, saling menghargai, saling mencintai diantara suami istri. Tidak rukunnya ibu bapak menyebabkan gelisahnya anak-anak, mereka menjadi takut,cemas, dan tidak tahan tinggal berada ditengahtengah orang tua yang tidak rukun. Maka anak-anak yang gelisah dan cemas itu mudah terdorong pada perbuatan-perbuatan yang merupakan ungkapan dari rasa hatinya, bosannya akan mengganggu ketentraman orang lain. Demikian juga halnya dengan anak-anak yang merasa kurang mendapat perhatian, kasih say- 
ang, dan pemeliharaan orang tua akan mencarikepuasan di luar rumah.

5. Diperkenalkannya secara populer obat-obat dan alat-alat anti hamil

Suatu hal yang sementara pejabat tidak sadari bahayanya terhadap moral anak-anak muda adalah diperkenalkannyasecara populer obat-obatan dan alat-alat yang digunakan untuk mencegah kehamilan. Seperti kita ketahui bahwa usia muda adalah usia yang baru mengalami dorongan seksual akibat pertumbuhan biologis yang dilaluinya, mereka belum mempunyai pengalaman, dan jika mereka juga belum mendapatkan didikan agama yang mendalam, mereka akan dengan mudah dibujuk oleh orangorang yang tidak baik, yang hanya melampiskan hawa nafsunya. Dengan demikian, akan terjadilah obat atau alat itu digunakan oleh anak-anak mudayang tidak terkecuali anak-anak sekolah atau mahasiswa yang dapat dibujuk oleh orang yang tidak baik itu, oleh karena kemauan mereka sendiri yang mengikuti arus darah mudanya, tanpa terkendali. Orang tidak ada yang tahu, karena bekasnya tidak terlihat dari luar.

6. Banyaknya tulisan, gambar, siaran, kesenian dan permainan yang tidak mengindahkan dasar-dasar dan tuntunan moral

Suatu hal yang belakangan ini kurang mendapat perhatian kita adalah tulisan-tulisan, bacaan-bacaan, lukisan-lukisan, siaran-siaran, kesenian-kesenian, dan permainan-permainan yang seolah-olahmendorong anak muda untuk mengikuti arus mudanya. Segi-segi moral dan mental kurang mendapat perhatian, hasil-hasil seniitu sekedar ungkapan dari keinginan dan kebutuhan yang sesungguhnya tidak dapat dipenuhi begitu saja. Lalu digambarkan dengan sangat realistis, sehingga semua yang tersimpan didalam hati anak-anak muda diungkap dan realisasinya terlihat dalam cerita, lukisan, atau permainan tersebut. Inipun mendorong anak-anak mudake jurang kemerosotan moral.

7. Kurang adanya bimbingan untuk mengisi waktu luang dengan cara yang baik, dan yang membawa kepada pembinaan moral

Suatu faktor yang juga telah ikut memudahkan rusaknya moral anak-anak muda ialah kurangnya bimbingan dalam mengisi waktu luang dengan yang baik dan sehat. Umur muda 
adalah umur yang suka berkhayal, melamunkan hal yang jauh. Kalau mereka dibiarkan tanpa bimbingan dalam mengisi waktunya, maka akan banyak lamunan dan kelakuan yang kurang sehat timbul dari mereka.

8. Tidak ada atau kurangnya markas-markas bimbingan dan penyuluhan bagi anak-anak dan pemuda-pemuda

Terakhir perlu dicatat, bahwa kurangnya markas bimbingan dan penyuluhan yang akan menampung dan menyalurkan anak-anak ke arah mental yang sehat. Dengan kurangnya atau tidak adanya tempat kembali bagi anak-anak yang gelisah dan butuh bimbingan itu, maka pergilah mereka berkelompok dan bergabung dengan anak-anak yang juga gelisah. Dari sini akan keluarlah model kelakuan yang kurang menyenangkan.

\section{d. Peranan Pendidikan Terhadap Pembentukan Kepribadian}

Setelah kita mengetahui penyebab anak-anak memiliki kepribadian buruk yang mengakibatkan merosotnya moral seperti yang diuraikan di atas, menunjukkan betapa pentingnya pendidikan agama bagi anak-anak kita, dan betapa pula besarnya bahaya yang terjadi akibat kurangnya pendidikan agama itu. Untuk itu perlu kiranya kita mencari jalan yang dapat mengantarkan kita pada terjaminnya kepribadian anak-anak yang kita harapkan menjadi warga negara yang cinta akan bangsa dan tanah airnya, dapat menciptakan dan memelihara ketentraman dan kebahagiaan masyarakat dan bangsa dikemudian hari.

Keluarga memiliki peranan yang sangat penting dalam pendidikan agama bagi anak-anaknya, terutama dalam pembentukan kepribadian. Menurut M.I Soelaeman (1978:66), salah satu fungsi keluarga adalah fungsi religius.Artinya keluarga berkewajiban memperkenalkan dan mengajak anak dan anggota keluarga lainnya kepada kehidupan beragama. Untuk melaksanakannya, orang tua sebagai tokoh-tokoh inti dalam keluarga itu terlebih dahulu harus menciptakan iklim religius dalam keluarga itu, yang dapat dihayati oleh seluruh anggotanya, terutama dengan anak-anaknya.

Pendidikan agama harus dimulai sejak dini, terutama dalam keluarga, sebab anak-anak pada usia tersebut siap untuk menerima ajaran agama yang berkaitan dengan keimanan kepada Allah tanpa 


\section{$104 \frac{\text { Jurnal AL-AFKAR }}{\text { Vol. II, No. II, Oktober } 2013}$}

harus menuntut dalil yang menguatkannya. Dalam pendidikan usia dini, ia juga tidak berkeinginan untuk memastikan atau membuktikan kebenaranajaran agama yang diterimanya.

Dalam penanaman pendidikan agama di lingkungan keluarga yang harus diberikan kepada anak-anak tidak terbatas kepada masalah ibadah,seperti sholat, zakat, puasa, mengaji, tetapi harus mencakup keseluruhan hidup, sehingga menjadi pengendali dalam segala tindakan. Bagi orang yang menyangka bahwa agama sempit, maka pendidikan agama terhadap anak-anak dianggap cukup dengan memanggil guru ngaji ke rumah atau menyuruh anaknya mengaji ke madrasah atau ke tempat lainnya. Padahal yang terpenting dalam penanam jiwa adalah didalam keluarga, dan harus terjadi melalui pengalaman hidup seorang anak dalam keluarga. Apa yang dilihat, dirasakan, dan didengar oleh anak sejak ia kecil akan mempengaruhi kepribadiannya.

Supaya pembinaan nilai-nilai agama itu betul-betul membuat kuatnya jiwaanak-anak untuk menghadapi tantangan segala zamandan suasana dikemudian hari, hendaknya ia dapat terbina sejak lahir, bahkan sejak dalam kandungan sampai ia mencapai usia dewasa dalam masyarakat.

Hasan Langgulung, ${ }^{13}$ mengemukakan bahwa pendidikan agamadan spiritual termasuk bidang-bidang pendidikan yang harusmendapat perhatian penuh oleh keluarga terhadap anak-anaknya. Pendidikan agama dan spritual ini berarti membangkitkan kekuatan dan kesediaan spiritual yang bersifat naluri yang ada pada anak-anak melalui bimbingan agama yang sehat dan mengamalkan ajaran-ajaran agama dan upacara-upacaranya. Begitu juga membekali anakanak dengan pengetahuan-pengetahuan agama dan kebudayaan Islam yang sesuai dengan umurnya dalam bidang aqidah, ibadah, mu'amalah dan sejarah. Begitu juga dengan mengajarkan kepadanya cara-cara untuk menunaikan syi'ar-syi'ar dan kewajiban-kewajiban agama, dan menolongnya mengembangkan sikap agama yang betul, dan yang pertama-tama yang harus ditanamkan adalah iman yang kuat kepada Allah, malaikat-malaikat-Nya, kitab-kitab-Nya, rasulrasul-Nya, hari kiamat, dan selalu mendapat pengawasan dari orang

13 Hasan Langgulung, Manusia dan Pendidikan Suatu Analisa Psikhologi dan Pendidikan. (Jakarta: Pustaka Al-Husna; 1986), hal. 56 
tua dalam segala perbuatan dan perkataannya.

Di antara cara-cara praktis yang patut dipergunakan oleh keluarga untuk menanamkan semangat keagamaan pada diri anakanak adalah sebagai berikut:

a. Memberi tauladan yang baik kepada mereka tentang kekuatan iman kepada Allah dan berpegang kepada ajaran-ajaran agama dalam bentuknya yang sempurna dalam waktu tertentu.

b. Membiasakan mereka menunaikan syi'ar-syi'ar agama semenjak kecil sehingga penunaian itu menjadi kebiasaan yang mendarah daging, mereka melakukannya dengan kemauan sendiridan merasa tentram sebab mereka melakukannya.

c. Menyiapkan suasana agamadan spritual yang sesuai di rumah dimana mereka berada.

d. Membimbing mereka membaca bacaan-bacaan agama yang berguna dan memikirkan ciptaan-ciptaan Allah dan makhlukmakhluknya untuk menjadikan bukti kehalusan sistem ciptaan itu dan atas wujud dan keagungan-Nya.

e. Menggalakkan mereka turut serta dalam aktivitas-aktivitas agama, dan lain-lain lagi, dengan cara-cara lain.

Ketika keluarga menunaikan hal-hal tersebut di atas, sebelumnya menurut kepada petunjuk dari al-Qur'an, as-Sunnah Nabi saw., dan peninggalan Assalaf-Assaleh yang semuanya mengajak untuk melaksanakan pendidikan, mengharuskan orang tua mendidikan anak-anaknya akan imandan akidah yang betuldan membiasakannya mengerjakan syari'at, terutama Shalat. Seperti firman Allah swt., "Perintahlah keluargamu bersembahyang dan tekunlah engkau mengerjakannya. Kami tidak minta darimu rezki . kami memberimu rezki. Akibat yang baik bagi yang bertaqwa." Sabda Rasul saw., "Perintahkanlah anak-anakmu untuk bersembahyang sedang mereka berumur tujuh tahun, pukullah mereka kalau tidak mau jika mereka berumur sepuluh tahun, dan pisahkanlah mereka dalam pembaringan." (HR. Abu Daud, Turmudzi, Ahmad dan al-Hakim)

Agama juga mewajibkan mereka menanamkan nilai-nilai agama dan kebiasaan-kebiasaan Islam pada jiwa anak-anakdan menyuruh mereka menghafal sebagian al-Qur'an, Sunnah Nabi saw., dan sejarah sahabat-sahabat dan khulafaurrasyidin supaya mereka terbimbing ke jalan yang lurus. Rasul saw. bersabda, "Hak anak kepada ibu 
bapaknya adalah bahwa ibu bapaknya mengajarkannya kitab Allah swt., memanah, berenang, dan memberinya warisan yang baik." Juga sabda Rasul saw., "Mencintai keluarga Nabi saw. dan membaca Al-Qur'an.”

Selain pendidikan agama seperti yang dijelaskan di atas, pendidikan akhlak dalam keluarga juga sangat besar pengaruhnya terhadap kepribadian anak. Tidaklah berlebihan kalau kita katakan bahwa pendidikan akhlakdalam pengertian Islam adalah bagian yang tidak dapat dipisahkan dari pendidikan agama. Sebab yang baik adalah yang dianggap baik oleh agama dan yang buruk adalah yang dianggap buruk oleh agama. Sehingga nilai-nilai akhlak, keuatamaan-keutamaan akhlak dalam masyarakat Islam adalah akhlak dan keutamaan yang di ajarkan oleh ulama. Sehingga orang muslim tidak sempurnaagamanya sehingga akhlaknya menjadi baik. Hampirhampir sepakat para filosof Islam, bahwa pendidikan akhlak adalah jiwa pendidikan Islam. Sebab tujuan tertinggi pendidikan Islam adalah mendidik jiwa dan akhlak.

Keluarga memegang peranan penting sekali dalam pendidikan akhlak untuk anak-anak sebagai institusi yang mula-mula sekali yang berinteraksi dengannya. Karena mereka mendapat pengaruh daripadanya atas segala tingkahlakunya. Oleh sebab itu haruslah keluarga mengambilberat tentang pendidikan ini, mengajar mereka akhlak yang mulia yang diajarkan Islamseperti kebenaran, kejujuran, keikhlasan, kesabaran, kasih sayang, cinta kebaikan, pemurah, berani, dan lain-lain sebagainya. Dia juga mengajarkan nilai dan faedahnya berpegang teguh pada akhlak di dalam hidup, membiasakan mereka berpegang kepada akhlak semenjak kecil. Sebab manusia itu sesuai dengan sifat asasinya menerima nasihat jika datangnya melalui rasa cinta dan kasih sayang, sedang ia menolaknya jika disertai dengan kekerasan dan biadab. Tepat sekali firman Allah swt., "Jika engkau (Hai Muhammad saw.) kasar dan bengis tentu mereka akan meninggalkanmu." (QS.3: 159)

Diantara kewajibankeluarga dalam penanaman akhlak kepada anak-anak agar memiliki kepribadian yang baik adalah sebagai berikut:

a. Memberi contoh yang baik bagi anak-anaknya dalam berpegang teguh kepadaakhlak mulia. Sebab orang tua yang tidak berha- 
sil menguasai dirinya tentulah tidak sanggup meyakinkan anakanaknya untuk memegang akhlakyang diajarkannya. Di antara kata-kata mutiarayang terkenal dari Ali ra. adalah "medan perang pertama adalah dirimu sendiri, jika kamu telah mengalahkannya, tentu kamu akan mengalahkan yang lain. Jika kalah disitu, niscaya ditempat lain kamu akan lebih kalah. Jadi berjuanglah disitu lebih dahulu”. tepat sekali Firman Allah SWT:"adakah kamu memerintahkan orang berbuat baik sedangkan kamu sendiri melupakan dirimu." (QS:2: 44)

b. Meluangkan bagi anak-anaknya pelung-peluang dan suasana praktis dimana mereka dapat mempraktekkan akhlak yang diterima dari orang tuanya.

c. Memberi tanggung jawab yang sesuaikepada anak-anaknya supaya mereka bebas memilih dalam tindak tanduknya.

d. Menunjukkan bahwa keluarga selalu mengawasi mereka dengan sadar dan bijaksana.

e. Menjaga mereka dari kawan-kawan yang menyeleweng dan tempat-tempat kerusakan, dan lain-lain lagi cara dimana keluarga dapat mendidik anak-anaknya. ${ }^{14}$

Di antara dalil-dalil yang digunakan pendidik-pendidik Islam tentang pentingnya pendidikan akhlak dan pentingnya peranan keluarga di situ, adalah Hadis yang diriwayatkan oleh Al-Bukhari dalam sejarahnya Nabi saw. bersabda, "Tidak memberi seorang bapak yang lebih baik melainkan akhlak yang baik."

Juga diriwayatkan dari al-Turmudzi dan al-Tabrani dari Jabir bin Samrah katanya Rasul saw. bersabda, "Jika seseorang mengajarkan anaknya lebih baik baginya daripada ia bersedekah setiap hari setengah gantang kepada orang miskin.” Diriwayatkan dari al-Baihaqi dari Ibnu Abbas, mereka berkata, "Wahai Rasulullah, engkau telah mengajar kami tentang hak orang tua terhadap anaknya. Maka apa pula hak anak terhadap orang tuanya?" Beliau bersabda, "Bahwa engkau memberi nama yang baik dan membaiki adabnya." Juga diriwayatkan bahwa Beliau saw. bersabda, "Muliakanlah anak-anakmu baikkanlah adab mereka!” (HR Ibnu Majah).

14 Abdullah Nasih Ulwan, Op. Cit., hal. 67 
$108 \frac{\text { Jurnal AL-AFKAR }}{\text { Vol. II, No. II, Oktober } 2013}$

\section{Kesimpulan}

Dari apa yang telah dipaparkan di atas, maka dapat ditarik beberapa kesimpulan sebagai berikut:

Lingkungan keluarga sangat besar peranannya dalam pembentukan kepribadian bagi anak-anak, karena dilingkungan keluargalah anak-anak pertama kali menerima pendidikan yang dapat mempengaruhi perkembangan anak selanjutnya.

Ada beberapa faktor yang menyebabkan buruknya kepribadian anak-anak yang dapat menimbulkan kemerosotan moral pada anakanak, diantaranya: (1) kurang tertanamnya nilai-nilai keimanan pada anak, (2) lingkungan masyarakat yang kurang baik, (3) pendidikan moral tidak berjalan semestinya, baik di keluarga, sekolah, dan masyarakat, (4) suasana rumah tangga yang kurang baik, (5) banyak diperkenalkan obat-obat terlarang dan alat-alat anti hamil, (6) banyak tulisan-tulisan, siaran-siaran, gambar-gambar yang tidak sejalan dengan nilai-nilai moral, (7) kurang adanya bimbingan dalam mengisi waktu luang dengan cara yang baik yang membawa kepada pembinaan moral, (8) kurangnya markas-markas bimbingan dan penyuluhan bagi anak-anak.

Agar anak-anak memiliki kepribadian yang baik dan terhindar dari pelanggaran-pelanggaran moral, maka perlu adanya pembinaan agama sejak dini kepada anak-anak dalamkeluargadan adanya kerjasama antara keluarga, sekolah, dan masyarakat. Sebaik apapun pendidikan moral dalam keluarga tanpa adanya dukungan dari sekolah dan masyarakat, sulit bagi anak-anak untuk memiliki kepribadian yang baik. Begitu juga pendidikan kepribadian di sekolah, tanpa adanya dukungan dari keluarga dan masyrakat, sulit bagi anak untuk memiliki kepribadian yang baik. Dengan demikian ketiga jenis lembaga ini tidak dapat dipisahkan dan harus saling mendukung.

Proses pembinaan nilai-nilai agama dalam membentuk kepribadian anak-anak dapat dimulai sejak anak lahir sampai dewasa. Ketika lahir diperkenalkan dengan kata-kata thayyibah, kemudian setelah mereka tumbuh dan berkembang menjadi anak-anak, maka yang pertama kali harus ditanamkan adalah nilai-nilai agama yang berkaitan dengan keimanan. Sehingga anak meyakini adanya Allah dan dapat mengenal Allah dengan seyakin-yakinnya (ma'rifatullah).

Bersama dengan itu, anak-anak juga dibimbing mengenai nilai- 
nilai moral, seperti cara bertutur kata yang baik, berpakaian yang baik, bergaul dengan baik, dan lain-lainnya. Kepada anak-anak juga ditamankan sifat-sifatyang baik, seperti sifat jujur, adil, hidup sederhana, sabar, dan lain-lainya. Selain itu, agar anak-anak memiliki moral yang baik didalam keluarga, khususnya antara ibu dan bapak juga harus menjaga harmonisasi hubungan antara keduanya dan harus menjadi suri tauladan bagi anak-anaknya.

\section{Daftar Pustaka}

Cakrawala Pendidikan Umum, Bandung: Ikatan Mahasiswa dan Alumni Pendidikan Umum (IMA-PU) PPS IKIP Bandung; 1999

..m.m.m.m.m. Filsafat dan Teosofat Akhlak, Bandung: Rizqi Press; 2011

Abdullah Nasih Ulwan, Pendidikan Anak dalam Islam, Jakarta: pustaka Imani; 2007

Djahiri. A. K, Menelusuri Dunia Efektif, pendidikan Nilai dan Moral, Bandung: Lab. PMP IKIP; 1966

Hasan Langgulung, Manusia dan Pendidikan Suatu Analisa Psikhologi dan Pendidikan. Jakarta: Pustaka Al-Husna; 1986

Ihat Hatimah dkk, Pembelajaran Berwawasan Masyarakat, Jakarta: Universitas terbuka; 2007

Linda N.Eyre Richard, Teaching Your Children Values. New York: Simon Sand Chuster; 1995

M.I. Seolaeman, Pendidikan dalam Keluarga. Diktat Kuliah; 1978

Rohmat Mulyana, Mengartikulasikan Pendidikan Nilai, Bandung: Alfabeta; 2004

Syamsu yusuf, Meretas Pendidikan Nilai, Bandung: Arfino Raya; 2007

Zakiah Dradjat, Membina Nilai-nilai Moral di Indonesia, Jakarta: Bulan Bintang; 1988 